\title{
PIRMINĖS SVEIKATOS PRIEŽIŪROS SPECIALISTŲ ŽINIOS APIE SUPŪLIAVUSI HIDRADENITĄ
}

\author{
Gintarė Kazbaraitė, Kristina Liesionytė \\ Lietuvos sveikatos moksly universiteto Medicinos akademijos Medicinos fakultetas
}

Raktažodžiai: supūliavęs hidradenitas, šeimos gydytojai.

\section{Santrauka}

Supūliavęs hidradenitas (lot. Hidradenitis suppurativa, SH) - lètinè, uždegiminė odos liga, pasireiškianti atsinaujinančiais skausmingais mazgais ir abscesais, besifomuojančiais sinusais bei takais tarp jų, randais. Tyrimo tikslas - įvertinti šeimos gydytojų žinias ir jų tikslumą apie supūliavusị hidradenitą bei žinių tikslumo priklausomybę nuo darbo stažo trukmès.

Atliktas vienmomentinis tyrimas, siekiant apklausti šeimos gydytojus. Tyrimo metodas - vienmomente anonimine anketinè apklausa. Apklausoje dalyvavo 35 šeimos gydytojai. Tyrimui atlikti parengta 18 klausimų originali anketa, kuri sudaryta remiantis Europos dermatologų forumo ekspertų sutarimu sudarytomis ir 2015 m. patvirtintomis Europos SH gydymo gairèmis. 14-18 balų rezultatas buvo vertinamas kaip pakankamas SH žinių tikslumas, o 0 - 14 balų rezultatas - kaip nepakankamos žinios apie SH.

Tyrimo rezultatai - tyrime dalyvavo 35 šeimos gydytojai: 27 ( 77,1 proc.) moterys ir 8 ( 22,9 proc.) vyrai. Vidutinis darbo stažas metais $27 \pm 13,18$. Gydytojų SH objektyvumo balų vidurkis $8,9 \pm 3,60$. Minimalus apklaustujų objektyvumas balais buvo 4 balai, o maksimalus -16 balų. 3 ( 8,6 proc.) šeimos gydytojų žinių apie SH objektyvumas buvo pakankamas. Né vienas respondentas i anketos klausimus neatsake 100 proc. tikslumu. Nèra statistiškai reikšmingo ryšio tarp šeimos gydytojų stažo trukmės ir SH žinių objektyvumo $(\mathrm{p}=0,615)$.

\section{İvadas}

Supūliavęs hidradenitas (lot. Hidradenitis suppurativa, SH) - lètinè, uždegiminė odos liga, pasireiškianti atsinaujinančiais skausmingais mazgais ir abscesais, besiformuojančiais sinusais, takais tarp jų, randais [1]. Dažniausiai SH prasideda pasibaigus brendimo laikotarpiui, apima plauko folikulus ir pasireiškia skausmingais, giliai odoje esančiais, uždegiminias dariniais, anatominėse apokrininių liaukų kūno vietose, dažniausiai pažastyse, kirkšnyse ar anogenitalinėse srityse [2]. Sergamumas SH Lietuvoje yra 23,5/100000 gyventojų. Vidutinis Lietuvos SH sergančiųjų amžius 34 metai. İdomu tai, jog 7,7 proc. visų sergančių pacientų buvo hospitalizuoti, o likusieji 92,3 proc. gydyti ambulatoriškai [3]. Tuo tarpu Europoje atliktų studijų duomenimis, sergamumo rodiklis siekè 1 proc., vidutinis sergančiujų amžius - 39 metai, o vyrų ir moterų sergamumo santykis $-1: 3[4,5]$.

Specifinių diagnostikos metodų SH neturi, todèl dažniausiai diagnozuojama remiantis patvirtintais klinikiniais diagnostikos kriterijais [6].

Pirminiai SH diagnostikos kriterijai:

- Skausmingi ar pūlingi dariniai, pasikartojantys daugiau nei 2 kartus per 6 mènesius.

- Mazgelių ar sinusų (uždegiminių ar neuždegiminių), abscesų, randų (besiformuojančių, atrofinių, hipertrofinių ar linijinių) atsiradimas pažastų, tarpvietès, sẻdmenų, genitalijų ar krūtinès srityse.

Antriniai SH diagnostikos kriterijai:

- Šeiminè SH anamnezè.

- Neigiamas žaizdos ar darinio pasèlio atsakymas, arba iprasta odos mikroflora.

SH sunkumas gali būti vertinamas remiantis įvairiomis skalèmis ir metodais. Dažniausiai liga vertinama pagal Hurley klasifikaciją [6] (1 lentelè).

SH gydymas priklauso nuo klinikinio ligos vaizdo ir jo sunkumo laipsnio ir skirstomas į: medikamentinị (sisteminis,

1 lentelè. Hurley klasifikacija

\begin{tabular}{|l|l|}
\hline $\begin{array}{l}\text { Hurley } \\
\text { stadija }\end{array}$ & Apibūdinimas \\
\hline I stadija & $\begin{array}{l}\text { Pavienio ar dauginių abscesų formavimasis, kuriam } \\
\text { vykstant nesusidaro sinusų takai. Nèra randèjimo. }\end{array}$ \\
\hline $\begin{array}{l}\text { II sta- } \\
\text { dija }\end{array}$ & $\begin{array}{l}\text { Pasikartojantys abscesai su sinusų takais ir vyks- } \\
\text { tančiu randejjimu. Viena ar daugiau plačiai pasi- } \\
\text { skirsčiusių pažaidų. }\end{array}$ \\
\hline $\begin{array}{l}\text { III } \\
\text { stadija }\end{array}$ & $\begin{array}{l}\text { Difuzinis paplitimas tarp keleto tarpusavyje susiju- } \\
\text { sių sinusų ir pūlinių. }\end{array}$ \\
\hline
\end{tabular}

Adresas susirašinėti: Kristina Liesionytė, el.p. kristina6717@gmail.com 
vietinis arba kompleksinis) ir chirurgini (2 lentelè). Visiems SH pacientams, nepaisant ligos sunkumo laipsnio, turi būti taikomas ir palaikomasis gydymas: skausmo ir svorio kontrolè, rūkymo atsisakymas, tinkami žaizdų tvarstymo metodai, psichoterapija [1].

Apie SH priežastis, vystymosi eigą, gydymą iki šiol mažai žinoma, todèl ši liga išlieka mịslè ịvairių specialybių gydytojams. Dėl savo klinikinès išraiškos ir gydytojų žinių tikslumo trūkumo apie šią ligą, SH diagnozuojamas ypač vèlai. Dažnai pirmieji specialistai, i kuriuos kreipiasi SH pacientai, dažniausiai yra šeimos gydytojai, todèl labai svarbu ịvertinti jų žinių tikslumą, susijusį su SH [7].

Tikslas - iqvertinti šeimos gydytojų žinias ir jų tikslumą apie supūliavusị hidradenitą bei žinių tikslumo priklausomybę nuo darbo stažo trukmès.

\section{Tyrimo medžiaga ir metodai}

LSMUL KK buvo organizuotas vienmomentinis tyrimas, siekiant apklausti šeimos gydytojus. Tyrimo metodas - vienmomente anoniminé anketinè apklausa. Tam, kad duomenys būtų kuo objektyvesni ir respondentai ị pateiktus klausimus atsakymų neieškotų literatūros šaltiniuose, anketinè apklausa buvo vykdoma 2017 metais sausio - kovo mènesiais Lietuvoje vykusių bendrosios praktikos gydytojų mokslinių praktinių konferencijų metu. Apklausoje dalyvavo 45 įvairių sričiu gydytojai ir 5 slaugytojai, tačiau tik šeimos gydytoju anketos buvo ịtrauktos ị tyrimą $(\mathrm{n}=35)$. Tyrimui atlikti parengta 18 klausimų originali anketa, kuri sudaryta remiantis Europos dermatologų forumo ekspertų sutarimu sudarytomis ir $2015 \mathrm{~m}$. patvirtintomis Europos SH gydymo gairemis. Gydytojų žinių tikslumas buvo vertinamas balais nuo 0 iki 18 , kiekvienam teisingam atsakymui suteikiant 1 balą. 14-18 balų rezultatas buvo vertinamas kaip pakankamas SH žinių tikslumas, o 0 - 14 balų rezultatas - kaip nepakankamos žinios apie SH. Esant neteisingam atsakymui, balai nebuvo mažinami. Duomenų analizè atlikta naudojant SPSS 24.0 programinị statistinès analizès paketą. Duomenys pateikti

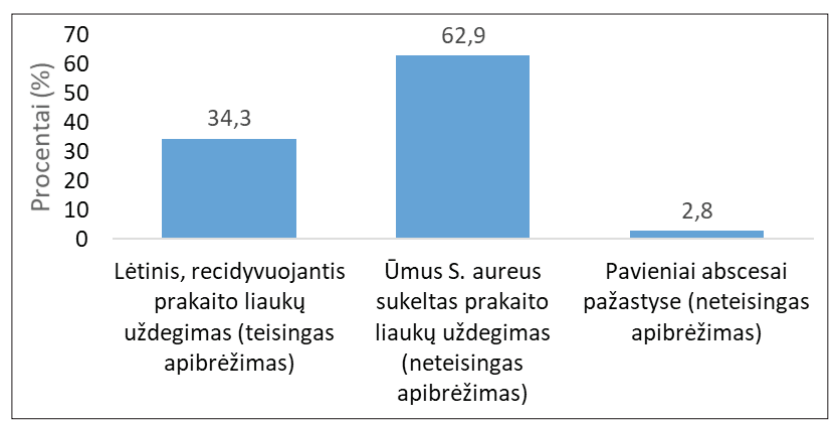

1 pav. Subjektyvi respondentų nuomonè apie supūliavusio hidradenito sąvoką
2 lentelè. SH gydymas (adaptuota pagal Gulliver W. et al. 2016; [1])

\begin{tabular}{|l|c|c|}
\hline $\begin{array}{l}\text { Pirmo pasirin- } \\
\text { kimo gydymas }\end{array}$ & $\begin{array}{c}\text { Antro pasirin- } \\
\text { kimo gydymas }\end{array}$ & $\begin{array}{c}\text { Trečio pasirin- } \\
\text { kimo gydymas }\end{array}$ \\
\hline $\begin{array}{l}\text { Klindamicino } \\
\text { losjonas }\end{array}$ & Resorcininolis & Dapsonas \\
\hline $\begin{array}{l}\text { Tetraciklinas } \\
\text { per os }\end{array}$ & Cinko gliukonatas & Botulino toksinas A \\
\hline $\begin{array}{l}\text { Klindamicino } \\
\text { ir rifampicino } \\
\text { derinys per os }\end{array}$ & $\begin{array}{c}\text { Kortikosteroidu } \\
\text { injekcija }\end{array}$ & Ciklosporinas A \\
\hline $\begin{array}{l}\text { Adalimumabas (po } \\
\text { oda) }\end{array}$ & Acitretinas & Hormoninè terapija \\
\hline $\begin{array}{l}\text { Chirurginis gydy- } \\
\text { mas }\end{array}$ & Infliksimabas & Izotretinoinas \\
\hline & $\begin{array}{c}\text { Sisteminiai korti- } \\
\text { kosteroidai }\end{array}$ & \\
\hline
\end{tabular}

vidurkio reikšme ir standartiniu nuokrypiu $(\mathrm{M} \pm \mathrm{SD})$ arba procentais. Ryšiui tarp dviejų kiekybinių dydžių nustatyti naudotas Pirson'o (Pearson) koreliacijos koeficientas. Duomenys laikyti statistiškai reikšmingais, kai $p<0,05$.

\section{Rezultatai ir jų aptarimas}

Tyrime dalyvavo 35 šeimos gydytojai: 27 (77,1 proc.) moterys ir 8 (22,9 proc.) vyrai. Vidutinis darbo stažas metais svyravo nuo 1 iki 50 metu, o vidutinis buvo $27 \pm 13,18$. Apklaustujų darbovietės ir atitinkamas jų skaičius: universitetinè ligoninè - 1 (2,9 proc.), rajono ligoninè - 1 (2,9 proc.), poliklinika - 21 (60,0 proc.), privati klinika - 12 (34,3 proc.) specialistų. Iš apklaustujų, 30 ( 85,7 proc.) gydytojų savo darbo praktikos metu buvo susidūrę su SH, o $5(14,3$ proc.) - ne.

Tyrime dalyvavusių respondentų buvo prašoma apibrěžti SH. 34,3 proc. $(n=12)$ teisingai, o 65,7 proc. $(n=23)$ - neteisingai apibrèžè SH sąvoką (1 pav.).

Tyrimo metu buvo nustatyta, kad 31,4 proc. $(n=11)$ gydytojų teisingai ịvardijo ligos vertinimo metodą (Hurley klasifikacija), o likusieji 68,6 proc. $(\mathrm{n}=24)$ pasirinko prakti-

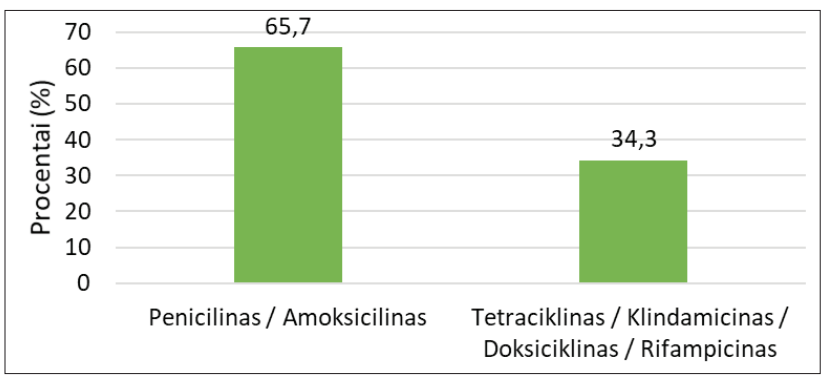

2 pav. Šeimos gydytojų nuomonė skiriant pirminị gydymą SH pacientams 
koje neegzistuojančią SH vertinimo skalę. 31,4 proc. $(\mathrm{n}=11)$ respondentų teisingai manè, jog SH negali būti užkrečiamas, nes tai neinfekcinès kilmès susirgimas, tuo tarpu 68,6 proc. $(n=24)$ teigè, kad SH gali būti užkrečiamas, jei pacientas yra imunosupresiškas.

Vertinant SH pacietų gydymo galimybes, tyrimo metu nustatyta, jog 65,7 proc. $(n=23)$ šeimos gydytojų SH gydymui rinktųsi penicilinų grupès antibiotikus, o 34,3 proc. $(\mathrm{n}=12)$ pacientus gydytų antibiotikoterapija, kuri atitinka SH gydymo gaires (2 pav.).

Gydytojų SH objektyvumo balu vidurkis $8,9 \pm 3,60$. Minimalus apklaustujų objektyvumas balais buvo 4 balai, o maksimalus -16 balų. 3 (8,6 proc.) šeimos gydytojų žinių apie SH tikslumas buvo pakankamas. Nè vienas respondentas $i$ anketos klausimus neatsake 100 proc. tikslumu. Nèra statistiškai reikšmingo ryšio tarp šeimos gydytojų stažo trukmès ir SH žinių tikslumo $(\mathrm{p}=0,615)$.

SH yra reta liga, todèl apie jos pasireiškimą, diagnostikos ir gydymo galimybes yra mažai žinoma tiek Lietuvoje, tiek visame pasaulyje. Pirminès sveikatos priežiūros specialistų indèlis ị SH diagnostiką ypač svarbus tiek pacientų gyvenimo kokybei, tiek dermatovenerologų ar chirurgų SH pacientų savalaikio gydymo organizavimui, todèl yra rengiami įvairūs praktiniai SH vadovai pirminés sveikatos priežiūros specialistams [7].

\section{Išvados}

1. Tyrime dalyvavusių šeimos gydytojų žinios apie $\mathrm{SH}$ nèra pakankamai tikslios.

2. Žinių apie SH tikslumas nepriklauso nuo šeimos gydytojų darbo stažo trukmès.

\section{Literatūra}

1. Gulliver W. Zouboulis CC. Prens E. et al. Evidence-based approach to the treatment of hidradenitis suppurativa/acne inversa, based on the European guidelines for hidradenitis suppurativa. Rev Endocr Metab Disord 2016 Feb 1.

https://doi.org/10.1007/s11154-016-9328-5

2. Zouboulis CC, Del Marmol V, Mrowietz U, Prens EP, Tzellos T, Jemec GBE. Hidradenitis suppurativa/acne inversa: criteria for diagnosis, severity assessment, classification and disease evaluation. Dermatology 2015:184-90.

https://doi.org/10.1159/000431175

3. Kazbaraitè G., Pilipaitytè L., Rimdeika R. Pūlingo hidradenito gydymas. Lietuvos bendrosios praktikos gydytojas, 2017; 21(2):116-120.
4. Revuz JE, Canoui-Poitrine F, Wolkenstein P. et al. Prevalence and factors associated with hidradenitis suppurativa: results from two case-control studies. J Am Acad Dermatol 2008;59:596-601.

https://doi.org/10.1016/j.jaad.2008.06.020

5. Jemec GB, Heidenheim M, Nielsen NH. The prevalence of hidradenitis suppurativa and its potential precursor lesions. J Am Acad Dermatol 1996;35:191-194.

https://doi.org/10.1016/S0190-9622(96)90321-7

6. Zouboulis CC, Desai N, Emtestam L. et al. European S1 guideline for the treatment of hidradenitis suppurativa/acne inversa. J Eur Acad Dermatol Venereol 2015;Apr, 29 (4):619-644.

https://doi.org/10.1111/jdv.12966

7. Woodruff CM, Charlie AM, Leslie KS. Hidradenitis suppurativa: a guide for the practicing physician. Mayo Clinic Proceedings 2015;90(12):1679-1693.

https://doi.org/10.1016/j.mayocp.2015.08.020

\section{PRIMARY CARE PHYSICIANS' KNOWLEDGE ABOUT HIDRADENITIS SUPPURATIVA \\ G. Kazbaraitė, K. Liesionytė}

Key words: hidradenitis suppurativa, primary care.

Summary

Hidradenitis suppurativa (HS) is a chronic, inflammatory, recurrent, debilitating skin disease of the hair follicle that often relentlessly progresses and presents after puberty. This rare disease manifests in painful lesions (multiple abscesses, sinus tracts, open comedones) that may cause hypertrophic scars and immobility.

Aim - to evaluate primary care physicians' knowledge about HS and objectivity association with experience duration.

Methods - a questionnaire study of general practitioners. There was 35 respondents. Original questionnaire was based on guideline on hidradenitis suppurativa developed by the Guideline Subcommittee of the European Dermatology Forum. 14-18 score was evaluated as sufficient knowledge about HS.

Results - there were 35 respondents: 27 (77,1\%) women and $8(22,9 \%)$ men. Mean experience duration was $27 \pm 13,18$ years. Mean objectivity score was $8,9 \pm 3,60(\min -\max =4-16) .3(8,6 \%)$ respondents had sufficient knowledge about HS. There was no significant correlation between primary care physicians knowledge sufficiency about HS and experience duration $(\mathrm{p}=0,615)$.

Correspondence to: kristina6717@gmail.com

Gauta 2017-05-18 